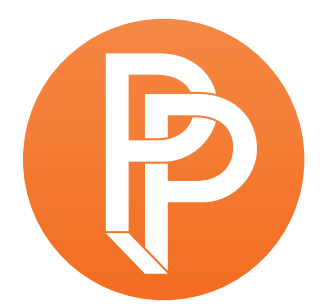

PERFORMANCE

PHILOSOPHY

\title{
THE PROCESSES OFEAVESDROPPING: WHERE TRAGEDY, COMEDY AND PHILOSOPHY CONVERGE
}

\author{
FREDDIE ROKEM TEL AVIV UNIVERSITY \\ Kafka eavesdropped on tradition, and he who listens hard does not see. \\ Walter Benjamin, letter to Gershom Scholem \\ (Benjamin and Scholem 1989, 224)
}

The motto I have chosen for this essay draws attention to the processes that take place in the 'scenic space' or the 'theatrical setting' within the contexts of which history and tradition can in some way be secretly overheard or watched through what we generally call 'eavesdropping', when someone secretly overhears a conversation or a meeting between others who are not aware of being monitored in this way. This is a distancing effect which is no doubt an important, more general aspect of Walter Benjamin's thinking - positioning himself as a thinker - though here characterizing Kafka, not himself, as eavesdropping on 'tradition'. While being separated from history by a 'screen', listening to or 'overhearing' tradition at some form of distance, listening hard, but without really seeing its full historical or cultural implications, Kafka as well as Benjamin, turn themselves into reflecting witnesses.

Another example of how eavesdropping is concerned with an attempt to understand the historical past, drawing attention to the sense of seeing rather than hearing, is Benjamin's well-known meditation on the Klee painting Angelus Novus, who, "[w]here we perceive a chain of events, he sees one single catastrophe which keeps piling wreckage and hurls it in front of his feet" (Benjamin 
1940). Humans can obviously not see what the angel can perceive from its supernatural 'metaperspective', eavesdropping on history from a distance, and in this case too without being directly involved in the events themselves. Benjamin's angel of history can only observe the past rather than taking an active part in new events as they unfold. According to Benjamin, however "[t]he angel would like to stay, awaken the dead, and make whole what has been smashed. But a storm is blowing from Paradise; it has got caught in his wings with such a violence that the angel can no longer close them" (Benjamin 1940). While the storm blowing from Paradise is separated from the debris, it is obviously in some way connected to it, influencing the inability of the angel to take on an active role in history. ${ }^{2}$

Eavesdropping is also synonymous with different forms of spying. This is not something new, but the methods for eavesdropping have become intensified with the electronic means of communication and recording developed during the last few decades. It is now possible to eavesdrop on a broad range of our daily, sometimes even most intimate activities, like writing mail or even taking notes. Surveillance cameras have become part of the urban landscape, not necessarily tracing my particular route in the city, but certainly being able to reconstruct it if necessary. In this article however, I want to examine some paradigmatic examples of eavesdropping from theatre and philosophy - analyzing the 'structures' and 'mechanisms' of eavesdropping in order to clarify some more general notions about the connections between the discursive practices of tragedy and comedy, on the one hand, and between drama/performance and philosophy, on the other. I want to suggest that eavesdropping serves as a multi-dimensional site or juncture where the different discursive practices converge and partially even overlap, thus further problematizing the exact borders between performance and philosophy.

I will begin in the 'beginning', with Plato's Symposium, depicting the celebration of Agathon's victory in the Lenaean tragedy competition in 416 B.C. At the very end of this dialogue - after Agathon himself as well as Aristophanes, Socrates and several other prominent Athenian intellectuals have engaged in an additional competition: a speech contest praising Eros, and after Alcibiades has finished his tirade against Socrates - it is only Socrates, the two playwrights and Aristodemus, who accompanied Socrates to the celebration, who are the remaining guests. At this point Socrates wants to convince Agathon and Aristophanes "that authors should be able to write both comedy and tragedy; the skillful tragic dramatist should also be a comic poet" (Plato 1994, 71, 223d). But as Apollodorus, who tells an unidentified companion about the celebration (with 'us' as Plato's readers 'eavesdropping' on this conversation) Agathon and Aristophanes as well as Aristodemus - who was present at the party and had told Apollodorus what he (Aristodemus) remembered several years afterwards - were too tired to follow Socrates' arguments and fell asleep. From the two initial contests - at the public festival and more privately, among the Athenians who have gathered for the celebration - a third agon, between the philosopher and the two playwrights emerges, personifying "the ancient quarrel between philosophy and poetry". 
Since Plato's text, no doubt intentionally, refrains from providing us with the details of Socrates' arguments, we must conjecture. Following previous readers, including Walter Benjamin whose interpretation of this passage I will refer to later, a possible reading (which I developed at length in my book Philosophers and Thespians (2010) emerges: that philosophy, as practiced by Socrates, unifies these two dramatic genres or discourses. Therefore, just as according to the well-known myth which Aristophanes had told in the speech-contest - most likely authored by Plato himself Eros is the force that reunites the two halves of the 'complete' four-legged creatures that had been cut in half by Zeus, philosophy is the discursive practice which can reunite the two dramatic forms of expression that for some reason had been separated. ${ }^{3}$ If the reason for dividing the four-legged humans into two two-legged creatures was to weaken their power, preventing them from being rebellious, while at the same time threatening them that if this rebelliousness continues Zeus would cut them in half one more time, making them hop around on one leg, the inherent subversivity of philosophy could also have been the reason for dividing philosophy into two dramatic genres, which Socrates now claims should be re-united. This can even be seen as clarifying Plato's position, writing the dialogue after Socrates had been sentenced to death by his Athenian fellow-citizens.

Moving freely between the notion of genre (tragedy and comedy) and their respective modalities (the tragic and the comic), Plato (and through him Socrates) seems to imply that philosophy is the discursive practice that integrates or unifies the two genres/modes of expression and thus, like the four-legged creatures in the myth, philosophy will again become more rebellious than either of these two dramatic genres by reuniting tragedy and comedy. According to Plato's master-narrative, Socrates had been sentenced to death by the Athenian democracy which perceived itself as being 'threatened' by his philosophy, while the arts and in particular the theatre, are to be banned from Plato's utopian state, where the philosopher-guardian rules. Depending on the particular perspective, both philosophy and the two dramatic genres have subversive potentials that the public authorities, either the Athenian polis or the philosopher kings in Plato's ideal state, seek to curb.

This interpretative strategy, drawing attention to processes of separation/division and (reJunification also raises important issues about the relations between the respective discursive practices of drama, theatre and performance on the one hand, and philosophy on the other, with regard to how they are constituted, or what Benjamin in his Trauerspiel book terms "the law of their structure" (dem Gesetz ihrer Bildung; Benjamin 2003, 127). The word translated by Osborne as 'structure' - Bildung - at the same time means the way in which they have been formed or constructed, as well as the way they serve the formation of knowledge through education and culture.

In what follows I want to focus on two issues, hoping to open up some new perspectives which have so far not been examined in depth with regard to Plato's dialogue and the theory of genre, or in the context of the interactions between Performance and Philosophy.

The two more specific issues I want to raise are: 
1. Is eavesdropping a 'crossing-point' or juncture where tragedy and comedy (the 'tragic' and the 'comic') meet and where they at least for a short but significant moment merge, even becoming indistinguishable?

2. And, assuming that eavesdropping is such a juncture between the two genres or modalities and their respective discursive practices: is this juncture of the dramatic genres and modalities also a possible site from which a philosophical discourse can emerge?

Scenes of eavesdropping or of 'noting' as it has frequently also been termed can be seen as a multifaceted and multivalent 'nothing', as Shakespeare would have it in his play Much Ado about Nothing, referring to illicit or concealed forms of overhearing that lead to "much ado". In such scenes usually a male spectator inside the fictional world, hiding behind a curtain, an 'arras' (or some kind of 'screen'), or even under a table, is inevitably drawn into the action 'again', while becoming radically affected or changed by what he has 'noted', frequently even paying with his life for this subversive action. Eavesdropping is a 'nothing' (or a non-presence) with dire consequences, exposing strong desires as well as causing much 'trouble', following Judith Butler's understanding of the notion of 'trouble', which like in Hamlet, with Polonius hiding behind the arras, involves a 'closet' (in Hamlet it is Gertrud's closet) as the point of origin for philosophical thinking (Butler 1990).

Among the not very many Classical Greek plays with eavesdropping scenes, I first want to mention Aristophanes' Thesmophoriazusae (411 B.C.; usually called The Poet and the Women) and the Bacchae by Euripides (405 B.C.). These plays were written and performed after the date of Agathon's victory celebration in 416 B.C. (when Plato himself was still quite young), but it is reasonable to assume that he was familiar with them when he composed the Symposium (generally considered to be between 385-70 B.C.). In both these plays male characters are eavesdropping on a group of women who are performing a ritual from which men were excluded. In Aristophanes' play Euripides sends a relative dressed up as a woman to this ritual in order to prevent the women from boycotting or punishing Euripides for his negative depictions of female characters (like Medea, Helen or Phaedra). ${ }^{4}$ The unnamed relative (fully visible, but hiding 'in' or 'behind' his attire, where the disguise is a weaker form of eavesdropping) is discovered and put on trial, while in the Bacchae the eavesdropping takes place off-stage, with Pentheus being discovered while secretly watching the ritual of the women after which he is brutally beheaded by his mother Agave.

We can of course not conclude from the fact that there are eavesdropping scenes in tragedies as well as in comedies that they serve as the juncture where the two genres meet or even merge, providing a conclusive answer to my first question. It seems, rather that there are crucial differences between eavesdropping in tragedies and comedies and that in tragedies the eavesdropper is severely punished, even by death, while in comedies eavesdropping leads to a complex negotiation, finally resolving the dramatic conflict after the eavesdropper is revealed.

However, two well-known examples from 'early' modern plays show more clearly how difficult it is to distinguish between the tragic and the comic modes in such scenes, even if the two plays themselves are clearly either a tragedy or a comedy. Because if we also consider the performative potentials of these scenes, both with three characters - one who hides, one who knows about the 
'set-up' and one who is unaware of the eavesdropping, a much more complex picture emerges, in particular because the spectators are invited to see (and eavesdrop) on the eavesdropping scene itself. I am referring to:

1. Polonius hiding behind the arras in Gertrude's 'closet' (in Hamlet, III, 4) in order to find out if Hamlet's love for Ophelia is the cause of his 'madness'.

2. And Orgon witnessing the exposure of Tartuffe's sexual avarice and hypocrisy through Elmire's 'mock-seduction', hiding under the table (in Tartuffe, IV, 5).

I want to suggest that both these scenes present a radical ambivalence with regard to how they can be characterized and performed. Eavesdropping scenes are based on obvious dramatic ironies with regard to who knows about the 'set-up' of eavesdropping, how it is discovered and what its consequences are. First they involve all the three characters in some form of danger, highlighting how guilt, vulnerability and the complicity (or involvement on the part of the 'innocent' character) in this subversive act are quickly re-distributed between the characters. Hamlet who is unknowingly watched becomes a murderer, unexpectedly taking "[a]rms against a sea of troubles", while Tartuffe is exposed by the 'almost' cuckolded husband who has until this moment been deceived by Tartuffe's hypocrisy. Both of these eavesdropping scenes expose complex distortions, where victims and victimizers quickly change roles and where the exposures they lead to, in all the senses of 'exposure', are both fatal and liberating at the same time.

The eavesdropper in different ways becomes a victim, with Polonius being stabbed and Orgon learning something not only about the hypocrisy of his trusted 'friend', but about the extraordinary seductive talents of his wife as well. Triggering anxieties, there is also something ridiculous about the situation, almost like a form of slapstick, where the eavesdropper in different ways is tempted to reveal himself. Polonius is revealed by trying to prevent the angry outbursts of Hamlet towards his mother in Hamlet, and Elmire's provocative seduction is no doubt perceived by Orgon as a threat to their marriage, and even if he was warned by her, he tries to interfere, creating an obvious comic effect. Both these eavesdropping scenes have both comic and tragic potentials in performance, producing a form of liminality where what is portentous is quickly transformed into something ridiculous and vice versa.

Issues of gender and sexuality are central in all the examples I have referred to so far, with the eavesdropper generally being a male figure that is ridiculed and pitied at the same time as he is exposed to some form of threat. But there are interesting exceptions to the male dominance among eavesdroppers, like in the second act of Ibsen's Rosmersholm where Rebecca West hides behind the curtain in Rosmer's bedroom to overhear what Rosmer and Kroll are discussing and what they know regarding the suicide of Beate, Rosmer's wife and Kroll's sister. Based on her desire for Rosmer the young and attractive woman Rebecca had convinced Beate to take her own life in her efforts to gradually 'take over' Rosmersholm, including Rosmer's bedroom where she hides behind the curtain, having entered the room from another door without the knowledge of Rosmer and Kroll. This is opposed to the two scenes in Hamlet and Tartuffe where the women (Gertrude and Elmire) are aware of the set-up. And in Rosmersholm, the moment Rebecca's wish to marry 
Rosmer can be realized she refuses, because of an incestuous relationship with her biological father, Dr. West which has been hidden even from her, not knowing that she is actually the daughter of the man with whom she had an intimate relationship. Learning this Rebecca decides to take her own life, inviting Rosmer to join her, jumping into the millrace meeting their deaths together, just as Beate had done.

The female eavesdroppers seem to be more complex psychologically than their male counterparts. Instead of becoming fools, confronting their 'mistakes', like Polonius and Orgon, the female eavesdroppers become self-destructive when their sexual desires cannot be realized. Feminine eavesdropping creates a complex dialectics between her (comic) wish and her (tragic) failure, internalizing the tensions, fusing the contradictions between the comic and the tragic. These dynamics can also be found in Hippolytus by Euripides, from 428 B.C., (twelve years before the celebration of Agathon's victory celebration in the Symposium) where we actually see Phaedra eavesdropping, while the Nurse and Hippolytus, both unaware that somebody is listening to them are situated behind the skene (Euripides 2010, lines 565-600). In this 'reversed' eavesdropping scene where the spectators see Phaedra eavesdropping at the door (not hiding behind the arras or under the table as Polonius and Orgon do), straining herself to hear what Hippolytus and the nurse are saying (or rather shouting) as the nurse reveals Phaedra's 'secret' to him. Phaedra then reports to the chorus (and the audience) what she has heard. And Euripides' play also leads to Phaedra's suicide, which in this case leads to complications with regard to Hippolytus' supposed 'guilt' which I will not examine in detail here. ${ }^{5}$

Eavesdropping is no doubt an extremely complex aspect of drama and performance, drawing attention to spectatorship in the theatre itself, with the spectators, in most cases, 'secretly' watching the events on the stage, reinforcing the meta-theatrical dimensions of the situation. Eavesdropping must also be considered within a larger set of practices of 'witnessing' (without being hidden), whereby the presence of spectators or witnesses inside the fictional world, like in the performance-within-the-play in Hamlet where the guilt of Claudius is supposedly exposed when he interrupts the performance, while at the same time being closely (and secretly) watched by Hamlet and Horatio. Eavesdropping scenes in a particular play usually appear in multiples, illuminating each other while at the same time there is a specific, climactic eavesdropping scene. The two scenes I referred to in Hamlet and Tartuffe are obvious examples of such a climactic eavesdropping scene.

When discussing the notion of eavesdropping we must also consider the appearance or presence of supernatural characters as well as the deus ex machina, appearing in the scenographic focus where the eavesdropper also frequently hides. The ghost in Hamlet is invisibly present and watches the events of the play from the very beginning from behind the "screen of death". The presence of the ghost triggers the action of the play, but as a creature from a supernatural world, he is not able to fully control the development of events, somewhat like Benjamin's angel. Thus, in order to give a full account of the closet-scene in Hamlet we must also take into consideration that there is another eavesdropper, the ghost, waiting to appear until the end of this scene. 
Walter Benjamin's discussion of these issues in his Origin of German Tragic Drama (2003), though without explicitly mentioning eavesdropping as a dramatic device, can serve as a transition to 'philosophical eavesdropping', which I want to suggest can also be seen as the site where the philosophical discourse originates. In the first section of his study, devoted to the relations between the Trauerspiel and tragedy, Benjamin locates the crucial juncture where tragedy and comedy converge, but without explicitly mentioning eavesdropping as such.

In the particular section I want to examine, returning to the Symposium - which had been the central text of the notoriously difficult Erkenntnisskritische Vorrede (translated as "Epistemo-Critical Prologue") - Benjamin discusses the final scene with Socrates and the two playwrights which I discussed before, which shows, Benjamin claims, that the dialogue "contains pure dramatic language, unfragmented by its dialectic of tragic and comic" (118). And, Benjamin adds,

\footnotetext{
With the intriguer comedy is introduced into the Trauerspiel. But not as an episode. Comedy - or more precisely: the pure joke - is the essential inner side of mourning which from time to time, like the lining of a dress at the hem or lapel, makes its presence felt. Its representative is linked to the representative of mourning. (Benjamin 2003, 125-6)

\begin{abstract}
Mit dem Intriganten zieht die Komik ins Trauerspiel ein. Sie ist darin jedoch nicht Episode. Die Komik - richtiger: der reine Spaß - ist die obligate Innenseite der Trauer, die ab und zu wie das Futter eines Kleides im Saum oder Revers zur Geltung [validity, fruition] kommt. Ihr Vertreter ist an den der Trauer gebunden.
\end{abstract}

On the basis of this metaphorical claim it is possible, I believe, to consider eavesdropping scenes to be such a "lining", where the comic has been folded into (tragic) mourning, or what Benjamin later terms, "the comic interior of the Trauerspiel" (das Lustspielinnere im Trauerspiel; 128).

Furthermore, according to Benjamin, Polonius and lago (and I would add Tartuffe) are based on the figure of what Benjamin terms the "demonic fool" through which the "Lustspiel enters into the Trauerspiel" and, he continues,

\footnotetext{
Through their modulation these two forms are not only empirically connected but in terms of the law of their structure they are as closely bound to each other as classical tragedy and comedy are opposed. [...] the Lustspiel [Benjamin concludes] shrinks (macht sich klein) and is, so to speak, absorbed [or transformed] into the Trauerspiel. (Benjamin 2003, 127; my emphasis)

Mit ihnen wandert das Lustspiel ins Trauerspiel ein. Denn solcherart ist die Gemeinschaft jener beiden Formen, welche durch Übergänge nicht nur empirisch sondern dem Gesetz ihrer Bildung nach so streng aneinander gebunden sind, wie Tragödie und Komödie sich gegensätzlich verhalten, daß das Lustspiel ins Trauerspiel wandert: niemals könnte das Trauerspiel im Lustspiel sich entfalten. Dies Bild hat seinen guten Sinn: das Lustspiel macht sich klein und geht gleichsam ins Trauerspiel hinüber.
} 
Eavesdropping is thus the lining through which this "law of their structure", their Bildung, to which I referred to be before, is realized and can also be perceived.

Plato's dialogues contain many variations on the eavesdropping situation through which philosophical thinking and discourses emerge. The cave parable in The Republic, for example, demonstrates in concrete visual terms how philosophical thinking emerges by "exposing" the falsehood of the shadows on the wall, revealing their true source to the prisoner who is released, while they appear (and are "exposed") as false photographic, second-degree images for those who have not perceived the true source of these shadows. In the Symposium the mystical teachings of Diotima from Mantinea are revealed from behind a veil of secrecy and distance, both in time and space as she is obviously not present at the celebration itself. And finally, at the very end of the Symposium, the sleep of the two playwrights is the veil behind which Socrates' ideas about the relations between tragedy and comedy remain hidden as the morning breaks, and Socrates got up and left with Aristodemus, as always. "He said that Socrates went directly to the Lyceum, washed up, spent the rest of the day as he always did, and only then, as evening was falling, went home to rest" (222b).

But there are also more direct and somewhat less metaphorical expressions of how philosophical discourses are constituted by eavesdropping scenes. The most obvious is no doubt Pythagoras' practice of lecturing to his students from behind a curtain, only allowing a select group of initiated students to be with him behind the curtain. Pythagoras developed the notion of 'veiled utterances' - akousmata - which can only be understood through a proper method of interpretation, corresponding to the 'scene' of philosophy itself.

It is interesting to think what the consequences of the suggestions I have presented here can be and I have not yet taken that step fully, and here I will only present a preliminary and very partial response to this issue. Assuming that the discursive practices of the theatre precede the full fruition of philosophy, which I believe Plato does by staging his philosopher as the person who can unify comedy and tragedy, it is important to pay attention to the fact that it is the eavesdropper who is transformed into the philosopher. Or put in the terms I have tried to develop here: the philosopher is a transgressor who runs the risk of victimization (if we follow the Polonius paradigm of tragedy) or is able to unveil hypocrisy (if we follow the Orgon paradigm of comedy). What Plato's Socrates argues is that the philosopher is both, coming from the place where comedy and tragedy can merge.

\section{Notes}

\footnotetext{
${ }^{1}$ This article is an expanded version of the short paper I presented at the conference Thinking through Tragedy and Comedy: Performance Philosophy and the Future of Genre that took place at the ICI in Berlin in December 2014: http://www.tragedycomedy.com/.
} 
2 The narrative device employed by Wim Wenders in his remarkable film Der Himmel über Betrlin (1987), in which two angels are eavesdropping on what is happening in this city, is based on this idea of eavesdropping as a distancing effect.

${ }^{3}$ The paradigm of unifying and dividing discursive practices will also serve Nietzsche in The Birth of Tragedy, but there it is two male divinities which are united, giving birth tragedy, and when they become separated, Socratic philosophy emerges.

${ }^{4}$ In this play Agathon also appears as a character, actually a rather comic one, because when Euripides tries to find women's clothes for his relative they approach Agathon, who they know sometimes dresses as a woman, but since Agathon is busy writing a female part for a new play, he needs his female attire. While no plays by Agathon have been preserved, Aristophanes' play and Plato's dialogue are the only sources depicting Agathon at some length.

${ }^{5}$ As Hippolytus and the Nurse enter the stage, after Phaedra has withdrawn from the door, Hippolytus first declares "How can I be quiet after the words I've heard?" (605) while she insists that he has promised her not to reveal anything of what he has learned from her about Phaedra's desire for him. At this point Hippolytus declares that "That oath was sworn by my tongue, not by my heart!" (612). This has become a key sentence in several philosophical contexts, beginning with Socrates in his initial exchange with Agathon in the Symposium, before he tells about Diotima's wisdom (199 a). Socrates refers ironically to the fact that he promised to make a eulogy while in fact he wanted to tell the truth. And in his seminal discussion of speech acts How to do things with words, J.L. Austin (1975) quotes this sentence in the passage delegitimizing drama and theatre for being insincere. What neither Socrates nor Austin fully recognize is that besides being a quote from a play (which can therefore not in Austin's case be taken 'seriously'), later on in the play itself, after Phaedra has committed suicide, accusing Hippolytus for having desired her in the letter she holds in her hand (after she has committed suicide), Hippolytus refuses to reveal the truth about her to his father. So he actually does not follow his own pronouncement that "That oath was sworn by my tongue, not by my heart!" In spite of threatening to tell the truth, even if he had promised to keep it secret, he does never break his initial promise. Thus the pronouncement itself is insincere or a kind of threat, which he does not realize or fulfill. There are also several instances in Aristophanes' plays where this sentence occurs. See also de Vries (2009).

\section{Works Cited}

Austin, J. L. How to Do Things with Words. Edited by J. O. Urmson. 2nd ed. New York: Oxford University Press, 1975. Benjamin, Walter. 2003. The Origin of German Tragic Drama. Translated by John Osborne. London: Verso.

. 1940. "On the Concept of History." Accessed December 7, 2014. http://www.sfu.ca/ andrewf/ CONCEPT2.html.

Benjamin, Walter and Gershom Scholem. 1989. The Correspondence of Walter Benjamin and Gershom Scholem, 19321940. Edited by Gerschom Scholem. Translated by Gary Smith and Andre Lefebre. New York: Schocken.

Butler, Judith. 1990. Gender Trouble: Feminism and the Subversion of Identity. New York: Routledge.

Euripides. (428 B.C.) 2010. Hippolytus. Translated by George Theodoridis. Accessed February 18, 2015. http://www. poetryintranslation.com/PITBR/Greek/Hippolytus.htm.

Plato. (ca. 385-370 B.C.) 1994. Symposium. Translated by Robert Waterfield. Oxford World's Classics. Oxford: Oxford University Press.

Rokem, Freddie. 2010. Philosophers and Thespians. Stanford: Stanford University Press.

de Vries, Hent. 2009. "Must We (Not) Mean What We Say? Seriousness and sincerity in the work of J.L. Austin and Stanley Cavell." In The Rhetoric of Sincerity, edited by Ernst van Alphen, Mieke Bal, and Carel Smith, 90-118. Stanford: Stanford University Press. 


\section{Biography}

Freddie Rokem holds the Emanuel Herzikowitz Chair for 19th and 20th Century Art and is Professor Emeritus from the Department of Theatre at Tel Aviv University, where he served as the Dean of the Yolanda and David Katz Faculty of 306 the Arts (2002-2006). His more recent books are Philosophers and Thespians: Thinking Performance (2010; translated to Italian and Polish); Jews and the Making of Modern German Theatre (2010, co-edited with Jeanette Malkin); Strindberg's Secret Codes (2004) and the prize-winning book Performing History: Theatrical Representations of the Past in Contemporary Theatre (2000; translated to German and Polish). He was the editor of Theatre Research International from 2006-2009, and is now co-editor of the new book series Performance Philosophy (Palgrave Macmillan). He has been a visiting Professor at universities in the United States, Germany, Sweden and Finland, and is also a translator and a dramaturg.

(c) 2015 Freddie Rokem

cc) (i) (-) Except where otherwise noted, this work is licensed under a Creative Commons Attribution-

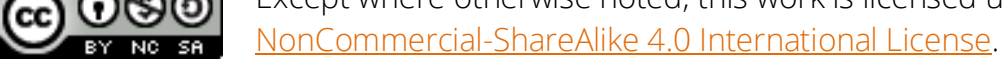

